\title{
국제사회의 2004년도 \\ 대 페루 원조현황
}

11.24 페루 국제협력청이 개최한 '국제사회의 2004년도 대 페루 원조현황 발표회' 를 개최한 바, 주 요 내용은 아래와 같음.

I . 회의 개요

- 일시/장소 : 11.24 17:00-19:00/ 외교부 회의실

- 참석자 : 페루 주재 원조기관, 국제기구, 대사 관, $\mathrm{NGO}$ 관계자 등 90 여명

- 페루측 참석자: 외교부 차관, 재경부 차관, 중앙 은행 총재 등

- 진행순서 : 외교부 차관의 축사, 국제협력청장 의 대 페루 원조현황 주요 내용 발표, 재경부차 관 - 중앙은행총재 - 세계은행 페루사무소장의 의견발표

\section{II. 주요 내용}

\section{1. 총 원조규모 : 390백만불}

- 페루정부 예산의 $2.9 \%$, 공공투자의 $23.2 \%$ 에 해당

- 공공부문 279.8백만불(71.7\%), 민간부문 110.2 백만불(28.3\%)

- 양자 219.6백만불(56.3\%), 다자 60.2백만불 (15.4\%), NGO 등 110.2 백만불(28.3\%)

※ 1998년과 비교시 양자간 원조규모는 5.2 백만 불, 다자간 원조규모는 11.4 백만불 감소, 반면 민간부문에 의한 원조는 59.1백만불에서 110.2 백만불로 크게 증가

\section{2. 중점지원분야(Sector)}

- 공공부문 capacity building 32.5\%

- 여성 및 사회개발 $15.1 \%$

• 의료보건 $12.5 \%$

• 농업 $11.1 \%$ 
- 교육 6.8\%

\section{3. 주요 원조국가}

\begin{tabular}{c|c|c}
\hline 금액 & 금액 & 비율 \\
\hline 미국 & 131.6 백만불 & $59.9 \%$ \\
독일 & 17.3 백만불 & $7.9 \%$ \\
스위스 & 11.5 백만불 & $5.2 \%$ \\
일본 & 11.3 백만불 & $5.1 \%$ \\
캐나다 & 9.5 백만불 & $4.3 \%$ \\
스페인 & 8.1 백만불 & $3.7 \%$ \\
이태리 & 5.9 백만불 & $2.7 \%$ \\
네덜란드 & 5.6 백만불 & $2.6 \%$ \\
노르웨이 & 4.1 백만불 & $1.9 \%$ \\
영국 & 4.0 백만불 & $1.8 \%$ \\
벨기에 & 3.1 백만불 & $1.4 \%$ \\
한국 & 2.96 백만불 & $1.3 \%$ \\
핀란드 & 1.7 백만불 & $0.8 \%$ \\
프랑스 & 1.2 백만불 & $0.6 \%$ \\
중국 & 1.2 백만불 & $0.5 \%$ \\
\hline
\end{tabular}

※상기 원조규모는 페루 국제협력청에 등록한 사업 기준

\section{4. 주요 국제(지역)기구}

\begin{tabular}{c|c|c}
\hline 금액 & 금액 & 비율 \\
\hline EU & 24.8 백만불 & $41.2 \%$ \\
UNDP & 12.6 백만불 & $20.9 \%$ \\
WB & 6.8 백만불 & $11.3 \%$ \\
UNICEF & 3.9 백만불 & $6.4 \%$ \\
WFP & 1.9 백만불 & $3.2 \%$ \\
UNFPA & 1.5 백만불 & $2.4 \%$ \\
PHO & 3.4 백만불 & $5.6 \%$ \\
(Panamerican Health Organization) & 2.3백만불 & $3.9 \%$ \\
IDB & & \\
(Inter-American Development Bank) & & \\
\hline
\end{tabular}

\section{5. 주요 원조대상지역, 원조규모 및 점유율, 빈곤율}

\begin{tabular}{c|c|c}
\hline 금액 & 금액 & 비율 \\
\hline Lima & 46.8 백만불(12\%) & $37.1 \%$ \\
San Martin주 & 24.0 백만불(6.2\%) & $57.1 \%$ \\
Ayacucho주 & 20.6 백만불(5.3\%) & $64.9 \%$ \\
Ucayali주 & 19.9 백만불(5.1\%) & $55.8 \%$ \\
Cusco주 & 19.4 백만불(5\%) & $59.2 \%$ \\
Huanuc0주 & 18.1 백만불(4.6\%) & $77.6 \%$ \\
\hline
\end{tabular}

※반면, 빈곤율이 높은 Huancavelica주는 8.1백만불, Puno주는 9.7백만불, Cajamarca주는 8.3백만불로 낮은 수준

- 빈곤율 : Huancavelica 84.4\%, Puno주 79.2\%, Cajamarca주 $74.2 \%$

※ 원조금액 중 120 백만불(30.8\%)은 national nivel에서, 270백만불(69.2\%)은 regional nivel에서 집행

\section{MDGs 부응 정도}

- 390백만불 중 260.9백만불(66.9\%)이 MDGs에 부응

빈곤 및 기아근절 $39 \%$, 환경지속가능성 보장 $14.3 \%$, 개발을 위한 글로벌 파트너쉽 조성 $3.9 \%$, 초 등교육 의무화 달성 $3.5 \%$, HIV 등 질병퇴치 $2.9 \%$

[자료 : 주페루 KOICA사무소] 